\title{
Human Enteric Coronaviruses
}

\author{
Brief Review
}

\author{
By \\ M. R. Macnaughton and H. A. Davies \\ Clinical Research Centre, Watford Road, Harrow, Middlesex, England \\ With 4 . Figures
}

Accepted September 3, 1981

\section{Introduction}

Coronaviruses are a group of lipid containing, enveloped RNA viruses with distinctive surface projections $(44,53,65)$. They cause serious infections in many animal species, including hepatitis and encephalitis in mice, bronchitis in chickens, encephalomyelitis in piglets and severe gastroenteritis in neonatal calves, piglets and dogs. In contrast, all of the more than 20 coronavirus strains so far positively isolated from man are in association with mild upper respiratory tract infections.

Since 1975, a number of reports have identified coronavirus-like particles (CVLPs) in faecal specimens from adults and children suffering from gastroenteritis and also from healthy subjects: these have been summarized previously $(21,29,40)$. Similar particles have been found in faecal samples from a number of animals. In all these studies, the presence of CVLPs was not clearly associated with disease and the particles were characterized as coronavirus-like entirely on their morphology, particularly the possession of surface projections approximately $20 \mathrm{~nm}$ long. The particles were pleomorphic and usually much larger than coronaviruses grown in cell culture. Although many attempts have been made to grow human CVLPs in organ and tissue cultures, all attempts have failed with the exception of two laboratories which have reported their growth either in organ cultures $(11,12)$ or in tissue cultures $(35,61)$, but both these reports require confirmation.

In this review, we describe the identification and classification of CVLPs from faecal material. A comparison is made between these particles and well-recognized coronaviruses. The relationship of CVLPs with disease and the apparent growth of CVLPs in culture are also discussed. A new evaluation is made of available data to consider whether some or any CVLPs should be classified as human enteric coronaviruses (HECVs). 


\section{Morphology of CVLPs Obtained from Faeces}

Many of the reports of the occurrence of CVLPs in faecal extracts contain micrographs of negatively-stained particles: Figure 1 shows a typical group of CVLPs found in studies in the United Kingdom. The particles are pleomorphic and enveloped $(4,12,16,37,43,48,56,61)$ : the shape can be round with a diameter $60-400 \mathrm{~nm}(4,12,37,43,56,61)$, oval and kidney-shaped of diameter $100-400 \mathrm{~nm}(12,43,56)$ with elongated forms up to $800 \mathrm{~nm}(43)$ or $1200 \mathrm{~nm}(56)$. They have been described as collapsed, which may be due either to the accumulation of stain on the surface of (14), or its penetration into the particles (16); others differ as they possess a central dense area $(4,12,14,61)$, A distinet electron-lucent rim with large patchy areas in seen in some particles $(11,12,37,43,56,61)$ which has not been found on those with a central dense area $(4,12,14,61)$.

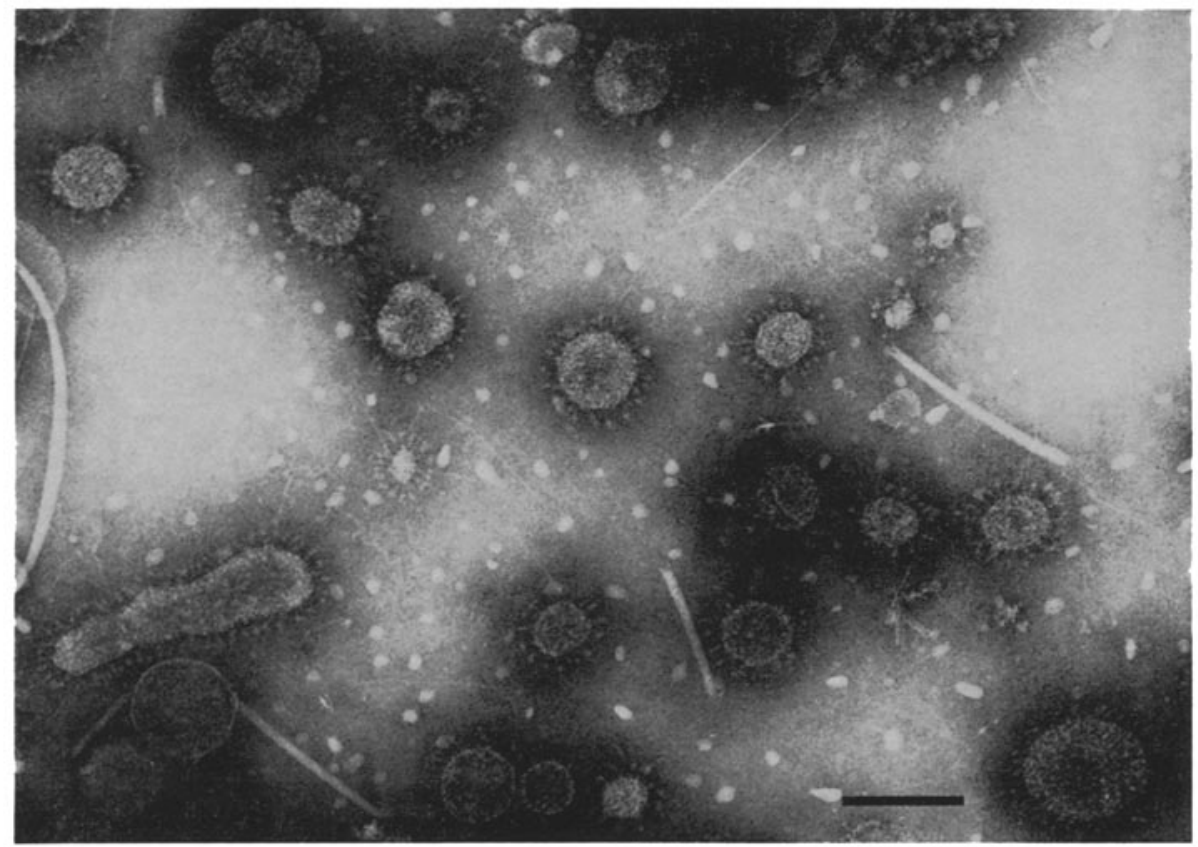

Fig. 1. CVLPs found in a faecal extract from a patient with gastroenteritis. The field shows pleomorphie particles surrounded by characteristically shaped surface projections. (Micrograph courtesy of Dr. E. O. Caul, P. H. L. Bristol.) Bar represents $200 \mathrm{~nm}$.

The length of the surface projections is in the range $20-46 \mathrm{~nm}(12,37,43,56$, $61)$ : they usually comprise a round or oval knob attached to the particle by a thin stalk $(12,37,43,56,61)$. Some projections possess an additional T-shaped structure at the distal end which yields an overall length of $44 \mathrm{~nm}(43,56)$. The morphological appearance can vary according to the negative stain used (9): only the round or oval knobs of the surface projections are visible using ammonium molybdate and the envelope appears penetrated when uranyl acetate is used. It is recommended that a standard stain should be used, for example 1.5 per cent potassium phosphotungstate at $\mathrm{pH} 6.5$. 
Fringed particles, presumably fragments of cell membranes (9), are frequently observed in faecal extracts. Care should be taken when analysing faecal samples to differentiate these cell membranes from CVLPs; CaUL et al. (9) have adequately described how CVLPs can be distinguished from fringed particles.

\section{Association with Gastroenteritis}

Numerous studies have described the identification of CVLPs in the faeces of adults and children with and without gastroenteritis. These include reports from Australia $(48,56,57)$, Costa Rica (42), France (61), Gambia (54), Germany $(4,37)$, Gilbert Islands (29), India (41, 43), Japan (64) and the United Kingdom (11, 15, $54,69,71)$. Many of the reports suggest that it is difficult to attribute a causative role to the CVLPs, as healthy individuals also shed CVLPs $(16,43,54,56,57)$. This is confused further by patients who shed CVLPs for periods of several months after the cessation of symptoms $(16,43,48,57)$, indicating that CVLPs may cause a chronic infection.

The occurrence of CVLPs varies greatly depending on the population studied. For example, CVLPs were found in nearly all faecal specimens examined from selected villages in the rural population of South India. They were not associated with any specific disease as they were found in healthy children and adults and in patients with chronic tropical sprue (43). The distribution of these particles in the population may reflect the frequency of intestinal morphological abnormalities and malabsorption in the symptom-free population of Southern India (43), or chronic excretion that continues after an episode of tropical sprue (MATHAN, personal communication). In rural Gambia, CVLPs were only observed in the faeces of a few children and their presence was not obviously related to diarrhoea (54). CVLPs have also been detected in the stools of Aboriginal children in Australia, with equal frequency in control and diarrhoeal individuals $(56,57)$. Thus these particles were clearly not associated with acute disease. However there may be a link in the more chronic cases of gastroenteritis found amongst Aboriginals.

In contrast, CVLPs have not been observed in most gastroenteritis studies carried out in Europe, Canada and the United States $(21,29,40)$. In addition, where reported, they have only been observed in the faeces of relatively few patients with gastroenteritis $(16,54,56,57)$. Furthermore, some of those patients shedding CVLPs have recently come from developing countries (54), where shedding of CVLPs in faeces is more common. It has been suggested from two studies $(16,48)$ that patients suffering from gastroenteritis in institutions for the mentally subnormal or psycho-geriatric units were more likely than normal individuals to shed CVLPs in their faeces, although a causal role could not be attributed to them (14). CVLPs have been detected in particularly acute outbreaks of gastroenteritis in a premature baby unit in Germany (37) and necrotizing enterocolitis in a maternity unit in France (61) in which a number of the babies died. In the latter case CVLPs were shed in the faeces of a high proportion of the babies.

It is not really clear what association CVLPs have with disease as there is much conflicting evidence. A report from the United Kingdom has shown that similar numbers of individuals with and without diarrhoea shed CVLPs in their faeces (16). However, CVLPs appear to be more frequently excreted by individuals 
in the non-Aboriginal population of Australia with diarrhoea than those with no diarrhoea (57).

\section{Growth in Tissue and Organ Cultures}

CVLPs, identified by electron microscopy in the faeces of neonates with necrotising enterocolitis in France (61), have been shown to replicate in HRT 18 cells, a cell-line derived from a human rectal adenocarcinoma $(34,35,36,61)$, although titres of infectious virus were not reported. These CVLPs have been considered by the authors to represent an HECV. No CPE was produced by the presumptive HECV in these cells, but immunofluorescence could be demonstrated using labelled antiserum against bovine enteric coronavirus (BECV). BECV has also been grown in HRT 18 cells in this laboratory (35) and it has been suggested by some workers that the human isolates may be BECV derived from a laboratory contamination as virus cross-contamination of tissue cultures can sometimes occur. At present it is difficult to confirm this suggestion. On the other hand, BECV has apparently been transmitted from infected calves to a laboratory worker with ensuing gastroenteritis (59) and antibodies to BECV have also been detected in human sera $(58,59)$.
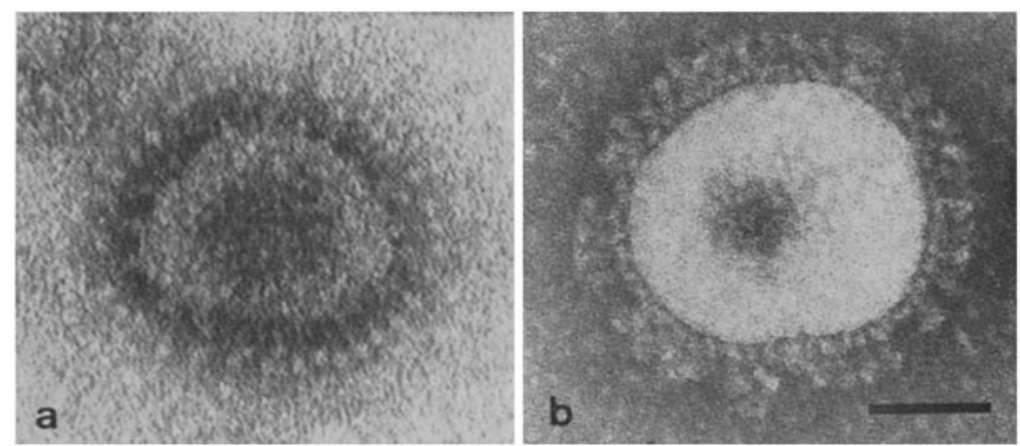

Fig. 2. $a$ CVLP from human foetal intestine organ culture fluid. This particle shows an envelope structure similar to coronaviruses. (Micrograph courtesy of Dr. E. O. Caul, P. H. L. Bristol.) $b$ CVLP from HRT 18 tissue culture fluid. Note the two sets of surface projections. Bar represents $50 \mathrm{~nm}$

These CVLPs have been grown in HRT 18 cells in this laboratory (DAvies and Macnadghton, unpublished results) and shown to be enveloped and fairly spherical with diameters ranging from $125-170 \mathrm{~nm}$. Typical examples are shown in Fig. $2 \mathrm{~b}$ which shows particles surrounded by two sets of surface projections; one set, $17-23 \mathrm{~nm}$ long, are slightly bulbous at the distal end and the shorter ones are 5-10 nm long and not individually distinct. The particles usually have a small central electron-dense area. The morphology of these particles is similar to BECV (LAPORTe, personal communication, 7), but the particles found in faeces from cases of necrotising enterocolitis (61) appear to bear no resemblance to those found in tissue culture fluid.

Faecal specimens from fifteen patients containing CVLPs were inoculated by CAUL, et al. $(11,12)$ into primary human embryo kidney monolayers and evidence 
of replication was observed by electron microscopy of tissue culture fluids and indirect immunofluorescence on the cells $(11,12)$. They reported that only one culture showed fluorescence using the patients' own convalescent serum. The intracellular changes observed were similar to those in coronavirus replication. This faecal extract was inoculated into human foetal intestinal organ cultures: a tenfold increase in the number of particles was found in the organ culture fluids at 24 hours compared with a 6 hour harvest. However, they were unable to passage material from this culture in cultures derived from several different human embryo kidneys. The morphology of the particles from the organ culture fluid was different from that of the particles found in faecal extracts in that they were less pleomorphic and no $\mathrm{T}$-shaped structures were seen on the surface projections (Fig. 2a). Some particles did not exhibit the electron-lucent rim described earlier.

The ultrastructural changes described in the columnar epithelial cells inoculated with these particles $(12,16)$ are in agreement with the published morphogenesis of coronaviruses (44). BRIDGER et al. (7) have described the morphogenesis of BECV in bovine foetal intestinal organ culture and many ultrastructural changes that they observed are similar to those of the CVLPs grown in organ culture. Tubular filaments of $9-10 \mathrm{~nm}$ in diameter, previously undescribed, were found by CAUL et al. (12) and these were proposed as being viral nucleocapsids. This is not in disagreement with the dimensions of nucleocapsids quoted for known coronaviruses $(10,32,38)$. Furthermore, they also found cytoplasmic inclusion bodies composed of tubules of $32 \mathrm{~nm}$ diameter which have also been found in cells infected with coronaviruses $(19,44)$. "Virus factories" have been described in BECV infected intestines by DovGHRI et al. (19) where areas within the cytoplasm, with or without a surrounding membrane, contain dense granular fibrillar matrix with virus cores inside; virus cores are also found in the distended endoplasmic reticulum. This feature was not described by CAUL et al. (12) or BRIDGER et al. (7). The evidence for the replication of the CVLPs presented by these authors appears convincing, although only one CVLP preparation showed this. Further studies are required to confirm this replication.

\section{Enteric CVLPs Isolated from Animals}

A number of coronaviruses have been identified that cause a variety of enteric diseases in animals $(44,65)$ and include canine coronavirus (CCV), a mouse hepatitis virus strain that cause lethal enteritis in infant mice (26), BECV and porcine transmissible gastroenteritis virus. These coronaviruses have been grown in tissue culture, shown on inoculation to cause enteric disease in the neonate and to have the morphological and biochemical characteristics of coronaviruses.

However, in recent years there have been several reports of CVLPs in faecal samples from a number of animals including dogs $(55,72)$, monkeys (13), cats $(30)$, sheep (68), rabbits (33) and calves (47). These CVLPs were morphologically similar to those found in human faeces, and as with human CVLPs they could not be shown to be involved in enteric disease. The CVLPs isolated in dogs $(55,72)$ and cats (30) are morphologically different from $\mathrm{CCV}(2,31,62)$ and a feline coronavirus that is closely related to feline infectious peritonitis virus $(50)$, which both produce enteritis in their hosts. One report (72) has described the occurrence of 
typical coronavirus particles and CVLPs, together with astroviruses and parvoviruses, in the same diarrheal stools of pups. It is interesting to note that only the CVLPs continued to be excreted after the cessation of diarrhoea and that convalescent sera obtained from the pups aggregated all the particles, except the CVLPs. The authors suggest that CVLPs may be antigenically altered coronavirus particles which thus are unable to react with the convalescent sera.

\section{Relationship of CVLPs to Coronaviruses}

Up to now CVLPs have been considered to be coronaviruses primarily on morphology, and there have been few published critical comparison between them and coronaviruses. The two types of CVLPs that have been described consist of CVLPs from faeces of children and adults and CVLPs from faeces of neonates grown in tissue culture. Particles representative of negatively stained preparations of human coronavirus strain 229E (HCV 229E), CVLPs from faeces and CVLPs grown in tissue culture are shown in Fig. 3, Fig. 1 and Fig. 2 b respectively.

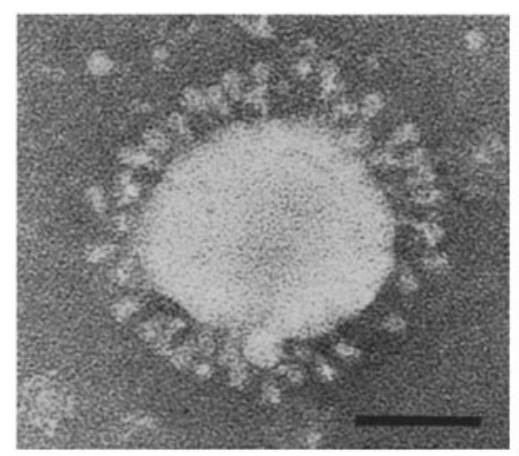

Fig. 3. Particle of HCV 229E, purified on sucrose gradient. Bar represents $50 \mathrm{~nm}$

The morphology of CVLPs from neonates grown in tissue culture (Fig. 2b) show many similarities to HCV 229E (Fig. 3), such as size and pleomorphism. It is difficult to compare the surface projections of these CVLPs to coronaviruses as the morphology of the surface projections of coronaviruses can vary (18). However, the tissue culture grown CVLPs possess two sets of projections of which one set is bulbous, resembling closely the projections of BECV (LAPORTE, personal communication, 7). Morphologically, these CVLPs appear to be coronaviruses.

On the other hand, there are a number of significant differences between CVLPs from faeces of adults and children (Fig. 1) and coronaviruses (Fig. 3). Although both particle types show a degree of pleomorphism, these CVLPs often show extreme pleomorphism. The surface projections of CVLPs and coronaviruses $(44,65)$ have a similar distribution with lengths of approximately $20 \mathrm{~nm}$. However, the shape of the CVLP projections differ from that of coronaviruses in that the former are thin projections with knobs at the distal end or occasionally with additional T-shapes $(9,12)$, while coronavirus projections of this structure have not been published and are usually bulbous (18). The envelope of most CVLPs appears 
densely stained except for a thin, ill-defined, unstained rim and patchy areas around the periphery. A rim structure, which is sharply defined, has been described in penetrated particles of BECV $(60)$, avian infectious bronchitis virus (5) and some CVLPs (14). Most reports describe typical coronavirus particles as having an envelope with a small central electron-dense area or "dimple" (44). Some of the CVLPs from the organ culture fluid have an envelope structure that resembles that of coronaviruses (12): an example is shown in Fig. 2 a. The ultrastructure of pelleted CVLPs from faeces has not been compared with that of coronaviruses. This is a difficult task as the internal structure of sectioned coronaviruses varies between strains (44). Fig. 4 shows an ultrathin section of pelleted, purified HCV 229E particles (Fig. 4a) and purified CVLPs (Fig. 4b). Both particle types have a distinct trilamellar membrane envelope, although HCV 229E possesses an internal electron-dense area which most CVLPs do not $(14,20)$. However, a small proportion of CVLPs have been shown to contain intermal structures (14): an example is shown in Fig. $4 \mathrm{~b}$.
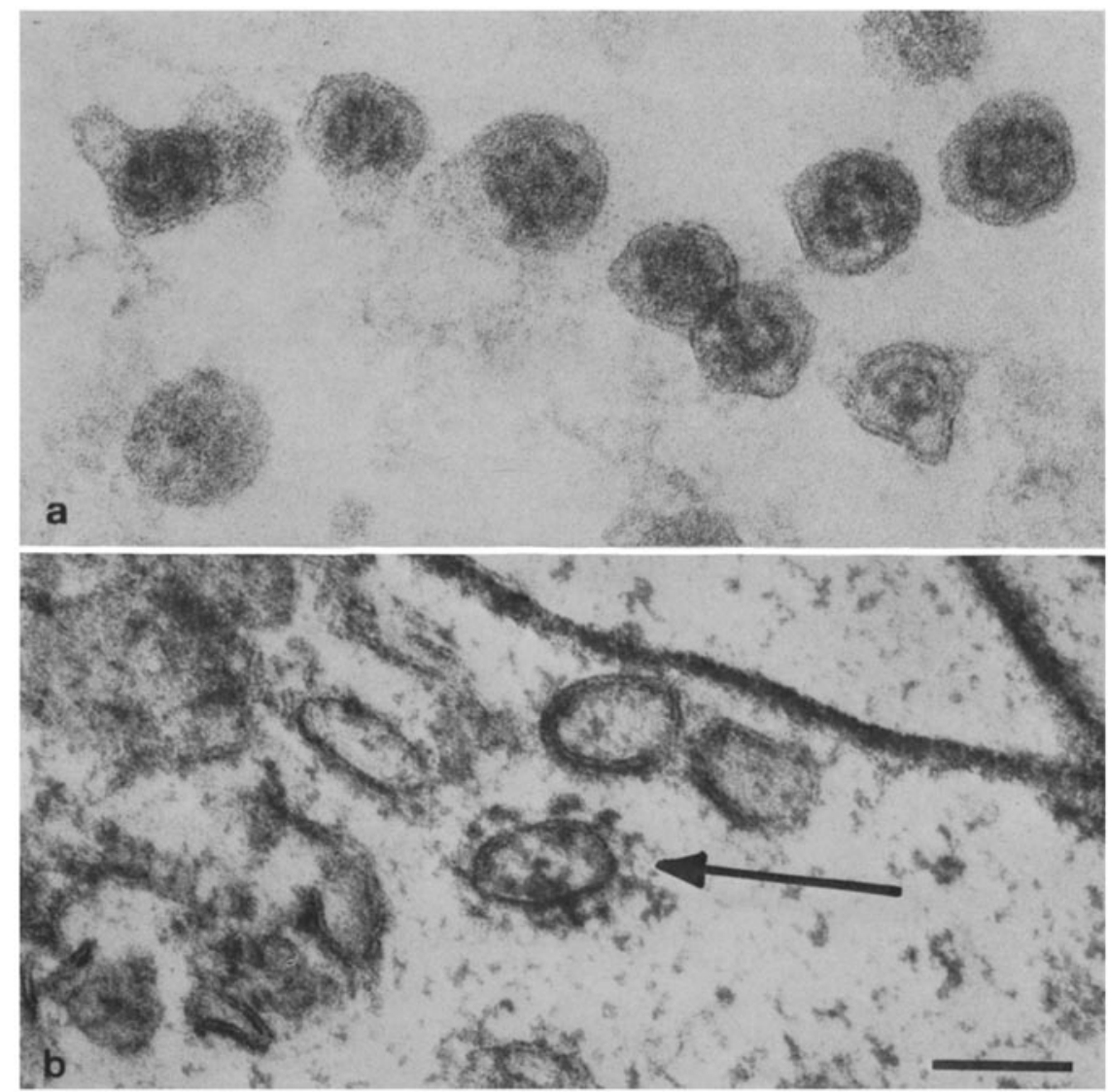

Fig. 4. $a$ Ultrathin section of pelleted HCV 229E purified on a sucrose gradient. $b$ Ultrathin section of pelleted CVLPs from faeces, purified on a sucrose gradient. The arrowed particle shows internal structures. (Micrograph courtesy of Dr. E. O. Caul, P. H. L. Bristol.) Bar represents $100 \mathrm{~nm}$ 
Early reports on coronaviruses classified them entirely on the basis of their unique morphology observed by electron microscopy $(44,66,67)$. However, the biochemical structure of most coronaviruses has now been determined and coronaviruses have been shown to possess a number of common characteristics $(53,65)$. These include the identification of a single high molecular weight single-stranded RNA of positive polarity, and three main polypeptide classes which comprise surface projection, envelope and RNP components. Such biochemical characteristics are now considered to be more appropriate than morphology in the identification of particles as coronaviruses. No biochemical studies have been reported for any CVLP preparation, and until such reports are forthcoming it is probably too early to consider classifying CVLPs as coronaviruses.

\section{HCV Tissue Tropisms}

Animal coronaviruses show a large variety of species and tissue tropisms (44). This is especially seen with IBV which can infect many different organs, including the upper and lower respiratory tract, the genital tract and the urinary tract, and can be recovered from the lung, spleen, tonsil and kidney of infected chickens (17, 27). Similarly, infectious MHV strain 3 particles have been found in the spleen, liver, brain, kidney, lung, heart, testioles and numerous other organs of infected mice (51). Other MHV strains also replicate in a variety of organs, although many of them have different target organs and cause a number of diseases including hepatitis, enteritis and demyelination (44). Most studies have so far reported only the replication of HCVs in the upper and lower respiratory tracts of man with the production of minor respiratory diseases $(6,44)$. However, pneumonia has been associated with coronavirus infection of both adults (46) and children (70). Furthermore RISKI and Hovr (52) have analysed paired sera from about 14,000 patients for antibody rises to $\mathrm{HCV} \mathrm{OC43,} \mathrm{and} \mathrm{have} \mathrm{shown} \mathrm{that} \mathrm{HCV}$ OC43 or antigenically related coronaviruses may be responsible in a few cases of more severe respiratory disease including pneumonia, and other non-respiratory diseases including certain neurological disorders. Such results are not unexpected as some HCV strains readily grow in a number of human cell lines $(44,65)$, in human macrophages (49) and even in suckling mouse brain (45).

These results may explain the appearance of coronaviruses in faeces of patients suffering from gastroenteritis: they may cause enteric diseases, although their isolation from faeces does not prove this. An alternative explanation is that these particles have no role in enteric disease, but that they are a result of respiratory infection and that their appearance in faeces is due to a later and probably minor infection of the gut. However, there is no documented evidence of respiratory symptoms preceding gastroenteritis in patients excreting these particles.

\section{Association of CVLPs with Other Diseases of Man}

CVLPs have also been observed in patients with a variety of other diseases including hepatitis $(28,73)$, malignant lymphoma $(3,22)$, multiple sclerosis $(8,25$, $63)$ and Balkan nephropathy $(1,23,24)$. In none of these cases were the CVLPs shown to be the cause of the disease, as in most of the reports, the CVLPs were 
identified by electron miscroscopy only, using negative stain or ultrathin sections. However, coronavirus particles were apparently grown in brains of suckling mice inoculated with brain specimens from patients with multiple sclerosis $(8,25)$. These isolates were serologically related to MHV strains A59 and JHM and HCV OC43, but not to HCV 229E (25), although it was not clear whether these viruses indeed came from the patients or were a contaminating mouse coronavirus, presumably MHV. Furthermore, another study has shown no significant differences in the levels of antibody to a number of coronaviruses in patients with nultiple selerosis, compared with controls (39). From the published electron micrographs, the morphology of these CVLPs closely resembles that of CVLPs isolated from faecal samples, and they show only the same superficial structural resemblance as most enteric CVLPs to coronaviruses. Thus similar CVLPs are found in a number of organs in the body as well as the gut in which they have been observed most frequently. At present it is impossible to determine the relationship of these CVLPs to enteric CVLPs, their role if any in infection, and their relationship to coronaviruses.

\section{Coneluding Comments}

The main purpose of this review has been to summarise the data on human CVLPs observed in faeces and to determine whether some or all of them are coronaviruses and whether they cause disease. The available evidence suggests that the CVLPs fall into two distinct groups. The major group of CVLPs has been observed in many parts of the world from children and adults with various forms of enteric disease, although a significant proportion of the uninfected population also shed these particles. There is no apparent correlation with disease in man and animals but this may be analagous to the situation of poliovirus excretion in man (21). Furthermore, these particles do not show a close structural relationship with coronaviruses and the reported growth in organ and tissue culture requires confirmation: purified CVLPs should be used and evidence of passage obtained. Many groups have tried to purify and analyse these particles and to grow them in organ and tissue culture and have reported no success. It is interesting to observe the many reports showing the presence of similar particles in a number of human tissues suggesting that they may not be a feature unique to the gut. Furthermore, no biochemical or antigenic studies on these particles have been reported. Thus, at this stage it is premature to classify them as HECVs and further work is required to correlate their role, if any, in infection, and their relationship to coronaviruses.

There are fewer reports of the second group of CVLPs, which have been observed by one group of workers, in the faeces of young babies suffering from severe enteric disease (61). Unfortunately, this group has not provided details of the structural characteristics of these particles, although they do seem to closely resemble coronaviruses. Furthermore, these particles have been shown to replicate in tissue culture (61), producing typical coronavirus particles. However, it is possible that these viruses may be of bovine origin, as they closely resemble a BECV that is also studied in that laboratory. Although no biochemical or antigenic studies have been reported for these particles, it seems reasonable at this stage to classify these particles as coronaviruses, but not yet as HECVs. 
Animal coronaviruses exhibit tropisms for many different tissues and some replicate in numerous tissues and organs besides their primary targets. It is not known whether human respiratory coronaviruses $(\mathrm{HCV}$ s) show similar tissue tropisms, but if they do, then coronaviruses found in faeces may be the result of respiratory infection with HCVs. Another possibility is that certain strains of $\mathrm{HCV}$ may be able to infect organs other than the respiratory tract as a primary target in certain individuals: perhaps these strains cause enterie disease in neonates. Further studies are required to answer these questions and determine which, if any, of these particles are HECVs.

\section{Acknowledgments}

We wish to thank our many colleagues for their useful advice, in particular Dr. E. O. Caul for some figures and $\mathrm{Dr}$. J. Laporte for supplying us with his isolate. We also thank Mrs. J. Gilbert for her patience in typing this manuscript.

\section{References}

1. Arostolov, K., Spasić, P., Bojanić, N.: Evidence of a viral aetiology in endemic (Balkan) nephropathy. Lancet i, 1271-1273 (1975).

2. Appel, M. J. G., Cooper, B. J., Greisen, H., Scott, F., Carmichael, L. E.: Canine viral enteritis. 1. Status report on corona- and parvo-like viral enteritis. Corn. Vet. 69, 123-133 (1979).

3. ARnold, W.: Identic viral infections in four eases of malignant lymphoepithelioma. Arch. Otorhinolaryngol. 220, 287-289 (1978).

4. Baumeister, H. G., Balks, H. G., MaAss, G.: Electromicroscopic visualization of virus particles in cases of gastroenteritis of infants and children. Klin. Wschr. $\mathbf{5 4}$, 445-448 (1976).

5. Berry, D. M., Cruickshank, J. G., Chu, H. P., Wells, R. H. J.: The structure of infectious bronchitis virus. Virology 23, 403-407 (1964).

6. Bradburne, A. F., Tyrrelc, D. A. J.: Coronaviruses of man. Progr. med. Virol. 13, $373-403$ (1971).

7. Bridger, J. C., CaUl, E. O., Egglestonk, S. I. : Replication of an enteric bovine coronavirus in intestinal organ cultures. Arch. Virol. 57, 43-51 (1978).

8. Burks, J. S., Devald, B. L., Jankovsky, L. D., Gerdes, J. C.: Two coronaviruses isolated from central nervous system of two multiple sclerosis patients. Science 209, $933-934(1980)$.

9. Caul, E. O., Ashley, C. R., Egglestone, S. I.: Recognition of human enteric coronaviruses by electron microscopy. Med. Lab. Sci. 34, 259-263 (1977).

10. Caul, E. O., Ashuey, C. R., Ferguson, M., Egglestone, S. I. : Preliminary studies on the isolation of coronavirus $229 \mathrm{E}$ nucleocapsids. FEMS Microbiol. Letts. 5, $101-105$ (1979).

11. CaUL, E. O., Clarke, S. K. R.: Coronaviruses propagated from patient with nonbacterial gastroenteritis. Lancet ii, 853-854 (1975).

12. CAUL, E. O., EGGLESTONE, S. T.: Further studies on human enteric coronaviruses. Arch. Virol. 54, 107-117 (1977).

13. CAUL, E. O., EGgLESTONe, S. I.: Coronavirus-like particles present in simian faeces. Vet. Ree. 104, $168-169(1979)$.

14. Caul, E. O., Egglestone, S. I.: Human enteric coronaviruses. In: Tyrrell, D. A. J., KaptKiax, A. (eds.), Virus Infections of the Gastrointestinal Tract. New York: Marcel Dekker. (In press.)

15. Caul, E. O., Paver, W. K., Clarke, S. K. R.: Coronavirus particles in faeces in patients with gastroenteritis. Lancet $\mathbf{i}, 1192(1975)$.

16. Clarke, S. K. R., Caut, E. O., Egglestone, S. I.: The human enterie coronaviruses. Postgrad. Med. J. 55, 135-142 (1979). 
17. Cook, J. K. A.: Duration of experimental infectious bronehitis in chickens. Res. Vet. Sci. 9, 506-514 (1968).

18. Davies, H. A., Macnaughton, M. R.: Comparison of the morphology of three coronaviruses. Arch. Virol. 59, 25-33 (1979).

19. Doughri, A. M., Storz, J., HaJer, I., Fernando, H. S.: Morphology and morphogenesis of a coronavirus infecting intestinal epithelial cells of newborn calves. Exp. Mol. Pathol. 25, 355-370 (1976).

20. Dourmashkin, R. R., Davies, H. A., Smith, H., Bird, R. G.: Are coronaviruslike particles seen in diarrhoea stools really viruses? Lancet ii, 971-972 (1980).

21. Flewetr, T. H., Boxali, E.: The hunt for viruses in infeetions of the alimentary system: an immunoelectronmicroscopical approach. Clin. Gastroent. 5, 359-385 (1976).

22. Friedmand, I., Brad, E. S.: Viruses in a malignant lymphoma. Lancet $\ddot{i}, 1013$ (1969).

23. Georgescu, L., Drosi, P., Butiu, I., Plavosin, L., Herzog, G.: Coronaviruses in Balkan nephritis. Amer. Heart. J. 99, 397-398 (1980).

24. Geongescu, L., Litvac, B., Diosi, P., Puavosin, L., Herzog, G.: Viruses in endemic (Balkan) nephropathy. Lancet $i, 1086$ (1976).

25. Gerdes, J. C., KuerN, I., DeVALd, B. L., Burks, J. S.: Coronavirus isolates SK and SD from multiple sclerosis patients are serologically related to murine coronaviruses $\mathrm{A59}$ and JHM and human coronavirus $\mathrm{OC43}$, but not to human coronavirus 229E. J. Virol. 38, 231-238 (1981).

26. Hterholzer, J. C., Broderson, J. R., Murphy, F. A.: New strain of mouse hepatitis virus as the cause of lethal enteritis in infant mice. Infect. Immun. 24, $508-522(1979)$.

27. Hofstad, M. S., Yoder, H. W. : Avian infectious bronchitis-virus distribution in tissues of chicks. Av. Dis. 10, 230-239 (1966).

28. Holmes, A. W., Deinhardt, F., Harris, W., Balt, F., Clime, G.: Coronaviruses and viral hepatitis. J. clin. Invest. 49, 45a (1970).

29. Holmes, I. H.: Viral gastroenteritis. Prog. med. Virol. 25, 1-36 (1979).

30. Hoshrno, Y., Scote, F. W.: Coronavirus-like particles in the faeces of normal cats. Arch. Virol. 63, 147-152 (1980).

31. Kefenan, K. P., Jervis, H. R., Marohwicki, R. H., Binn, L. N.: Intestinal infection of neonatal dogs with canine coronavirus 1-71: Studies by virologie, histologic, histochemical, and immunofluorescent technies. Amer. J. vet. Res. 37, $247-256(1976)$.

32. KenNedy, D. A., Johnson-Lussenbura, C. M.: Isolation and morphology of the internal component of human coronavirus, strain $229 \mathrm{E}$. Intervirology 6, 197-206 $(1975 / 76)$.

33. Lapterre, J., Marsolais, G., Pilon, P., Descôteaux, J.-P.: Preliminary report on the observation of a coronavirus in the intestine of the laboratory rabbit. Canad. J. Microbiol. 26, 1204-1208 (1980).

34. Laporte, J., Bobulesco, P.: Growth of human and canine enteritic coronaviruses in a highly susceptible cell line - HRT-18. In: Pollakd, M. (ed.), Perspectives in Virology, Vol. XI, 189-193. New York: Alan R. Liss 1981.

35. Laporte, J., Bobulesco, P., Rossi, F.: Une lignée cellulaire particulièrement sensible à la réplication du coronavirus entéritique bovin: les cellules HRT18. C. R. Acad. Sc. Paris 290, 623-626 (1980).

36. Laporte, J., L'Hakidon, R., Bobulasco, P.: In witro culture of bovine enteritic coronavirus (BEC). In: Viral enteritis in humans and animals (Thiverval Grignon, France 1979) 90, 99-102. Paris: INSERM.

37. MaAss, G., Baumetster, H. G., Freitag, N.: Viren als Ursache der akuten Gastroenteritis bei Säuglingen und Kleinkindern. Münch. med. Wschr. 119, 1029-1034 (1977).

38. Macnaughton, M. R., Davies, H. A., Nermut, M. V.: Ribonucleoprotein-like structures from coronavirus particles. J. gen. Virol. 39, 545-549 (1978). 
39. Madden, D. L., Wallen, W. C., Houff, S. A., Letnlkki, P. A., Sever, J. L., Holmes, K. A., Castellano, G. A., Shekarchi, I. C.: Coronavirus antibodies in sera from patients with multiple sclerosis and matched controls. Arch. Neurol. 38, 209-210 (1981).

40. Madelex, C. R.: Viral infeetions. Clin. Gastroent., Suppl. 1, 105-124 (1980).

41. Marya, P. P., Pereira, S. M., Mathan, M., Bhat, P., Albert, M. J., Baker, S. J.: Aetiology of acute gastroenteritis in infancy and early childhood in southern India. Arch. Dis. Child. 52, 482-485 (1977).

42. Mata, L., Urrutta, J, J., Serrato, G., Mohs, E., Chrs, T. D. Y.: Viral infections during pregnancy and in early life. Amer. J. Clin. Nutr. 30, 1834-1842 (1977).

43. Mathan, M., Mathan, V. I., Swaminathan, S. P., Yesudoss, S., Baker, S. J.: Pleomorphic virus-like particles in human faeces. Lancet $i, 1068-1069$ (1975).

44. Molntosh, K.: Coronaviruses: a comparative review. Curr. Top. Microbiol. Immunol. 63, 85-129 (1974).

45. McINTosh, K., Becker, W. B., Chavock, R. M.; Growth in suckling mouse brain of "IBV-like" viruses from patients with upper respiratory tract disease. Proc. Nat. Acad. Sci. U.S.A. 58, 2268-2273 (1967).

46. Molntosh, K., Chao, R. K., Krause, H. E., Wasu, R., Mochga, H. E., Mufson. M. A.: Coronavirus infection in acute lower respiratory tract disease of infants, J. inf. Dis. 130, 502-507 (1974).

47. MoNulty, M. S., Curran, W. L., McFerran, J. B.: Virus-like particles in calves' faeces. Lancet î, $78-79$ (1975).

48. Moore, B., Leie, P., Hewish, M., Dixon, B., Mukherjeie, T.: Coronaviruses in training centre for intellectually retarded. Lancet $\mathbf{i}, 261$ (1977).

49. Patterson, S., Macnadghton, M. R.: Replication of human respiratory coronavirus strain 229E in human macrophages. (Submitted for publication, 1981.)

50. Pedersen, N. C., Boyle, J. F., Floyd, K., Fudge, A., Barker, J.: An enteric coronavirus infection of cats and its relationship to feline infectious peritonitis. Amer. J. vet. Res. 42, 368-377 (1981).

51. PIAzZA, M.: The fate of MHV-3 after intravenous injection into susceptible mice. Arch. ges. Virusforsch, 22, 472-4.74 (1967).

52. RIsKI, H., HovI, T.: Coronavirus infections of man associated with diseases other than the common cold. J. med. Virol. 6, 259-265 (1980).

53. Robb, J. A., Bond, C. W.: Coronaviridae. In: Fraenkel-Conrat, H., Wagner, R. R. (eds.), Comprehensive Virology, Vol. 14, 1-8. New York: Plenum Press 1979.

54. Rowland, M. G. M., Davmes, H., Patterson, S., Dourmashikin, R. R., Tyrrelu, D. A. J., Mathews, T. H. J., Parry, J., Hall, J., Larson, H. E.: Viruses and diarrhoea in West Africa and London: a collaborative study. Trans. R. Soc. trop. Med. Hyg. 72, 95-98 (1978).

55. Schnagi, R. D., Holmes, I. H.: Coronavirus-like particles in stools from dogs from some country areas of Australia. Vet. Rec. 102, 528-529 (1978).

56. Schnagl, R. D., Hormes, I. H., Mackay-Scollax, E. M.: Coronavirus-like particles in Aboriginals and Non-Aboriginals in Western Australia. Med. J. Aust. 1, $307-309$ (1978).

57. Sohnagu, R. D., Moret, F., Holmes, I. H.: Rotavirus, coronavirus-like particles, bacteria and parasites in Central Australia. Med. J. Aust, 2, 115--118 (1979).

58. Sharpee, R., Mebus, C. A.: Rotaviruses of man and animals. Lancet i, 639 (1975).

59. Stokz, J., Roxt, R. : Reactivity of antibodies in human serum with antigens of an enteropathogenie bovine coronavirus. Med. Microbiol. Immunol. 169, 169-178 (1981).

60. Storz, J., Rotr, R., Kaluza, G.: Enhancement of plaque formation and cell fusion of an enteropathogenic coronavirus by trypsin treatment. Infect. Inamun. 31, $1214-1222(1981)$.

61. Suread, C., Amiel-Tison, C., Moscovici, O., Lebon, P., Laporte, J., Chany, C.: Une épidémie d'entérocolitis ulcéronécrosantes en matemité. Arguments en faveur de son origine virale. Bull. Acad. Nat. Méd. 164, 286-293 (1980). 
62. Takeuchi, A., Binn, L. N., Jervis, H. R., Keenan, K. P., Hrldebrandt, P. K., Vatas, R. B., BLAND, F. F.: Electron microscope study of experimental enteric infection in neonatal dogs with a canine coronavirus. Lab. Invest. 34, 539-549 (1976).

63. TANaka, R., Iwasaki, Y., Kopeowski, H. J.: Intracisternal virus-like particles in brain of a multiple sclerosis patient. J. Neurol. Sci. 28, 121-126 (1976).

64. Taniguchi, K., Uraswa, S., Urasawa, T.: Further studies of 35-40-nm virus like particles associated with outbreaks of acute gastroenteritis. J. med. Microbiol. 14, $107-118$ (1981).

65. Tyrretu, D. A. J., Alexander, D. J., Almeida, J. D., Cunntwgham, C. H., Easterday, B. C., Garwes, D. J., Hierholzer, J. C., Kapikian, A., MaCnaUghton, M. R., MoIntosh, K. Coronaviridae: second report. Intervirology 10, $321-328(1978)$.

66. Tyrrele, D. A. J., Almemda, J. D., Berry, D. M., Cunningham, C. H., Hamre, D., Hofstad, M. S., Malludr, L., McIntosh, K.: Coronaviruses. Nature 220, 650 (1968).

67. Tyrreld, D. A. J., Almempa, J. D., Cunningham, C. H., Dowdie, W. R., Hofstad, M. S., MoIntosir, K., Ta.mima, M., Zarkstelskaya, L. YA., Easterday, B. C., KaptKtaN, A., BINGHAM, R. W.: Coronaviridae. Intervirology 5, $76-82$ (1975).

68. Tzipori, S., Smrth, M., Makin, T.: Enteric coronavirus-like particles in sheep. Aust. Vet. J. 54, 320-321 (1978).

69. Wempling, A. M., WALKeR-SMrtm, J.A., BrRd, R. : Micro-organisms in outpatient infantile gastroenteritis. Arch. Dis. Child. 55, 185-188 (1980).

70. Wenzes, R. P., Hendley, J. O., Davies, J. A., Gwaltwey, J. M. : Coronavirus infections in military recruits. Three year study with coronavirus strains OC43 and 229E. Amer. Rev. Respir. Dis. 109, 621-624 (1974).

71. WHITBY, H. J., Rodgers, F. G.: Detection of virus particles by electron microscopy with polyacrylamide hydrogel. J. clin. Pathol. 33, 484-487 (1980).

72. Williams, F. P.: Astrovirus-like, coronavirus-like, and parvovirus-like particies detected in diarrheal stools of beagle pups. Arch. Virol. 66, 215-226 (1980).

73. Zuckerman, A. J., Taylor, P. E., Almeida, J. D.: Presence of particles other than the Australia-SH antigen in a case of chronic active hepatitis with cirrhosis. Brit. med. J. i, 262-264 (1970).

Authors' address: Dr. M. R. Madnaughtox, Division of Communicable Diseases, Clinical Research Centre, Watford Road, Harrow, Middlesex HA 1 3UJ, England.

Received July 23, 1981 